\title{
Fermentation of Pretreated Herbaceous Cellulosic Wastes to Ethanol by Anaerobic Cellulolytic and Saccharolytic Thermophilic Clostridia
}

\author{
Kutateladze L*, Urushadze T, Dudauri T, Metreveli B, Zakariashvili N, Xhoxhashvili I and Jobava M \\ Durmishidze Institute of Biochemistry and Biotechnology, Agricultural University of Georgia, Georgia
}

Received: 帮: October 11, 2018; Published: 監: October 25, 2018

*Corresponding author: Kutateladze L, Agricultural University of Georgia, Durmishidze Institute of Biochemistry and Biotechnology, University Campus of Digomi, David Agmashenebeli Alley 240, Tbilisi-Georgia

\begin{abstract}
Lignocellulosic waste streams from agriculture, paper and wood industry are renewable, plentiful and low-cost raw materials that can be used for large-scale production of liquid and gaseous biofuels. As opposed to prevailing multi-stage biotechnological processes developed for bioconversion of cellulosic substrates to ethanol where high cost cellulase preparations are used, consolidated Bioprocessing (CBP) offers to accomplish cellulose and xylan hydrolysis followed by fermentation of both C6 and C5 sugars to ethanol in a single-stage process. Syntrophic microbial consortium comprising of anaerobic, thermophilic, cellulolytic, and saccharolytic bacteria in the genus Clostridia with improved ethanol productivity and high tolerance to fermentation end-products had been proposed for achieving CBP. 65 new strains of anaerobic thermophilic cellulolytic and saccharolytic Clostridia were isolated from different wetlands and hot springs in Georgia.

Using new isolates, fermentation of mechanically pretreated wheat straw and corn stalks was done under oxygen free nitrogen environment in thermophilic conditions $\left(\mathrm{T}=55^{\circ} \mathrm{C}\right)$ and $\mathrm{pH}$ 7.1. Process duration was 120 hours. Liquid and gaseous products of fermentation were analyzed on the daily basis using Perkin Elmer gas chromatographs with flame ionization and thermal detectors. Residual cellulose, xylan, xylose and glucose were determined using standard methods. Cellulolytic and saccharolytic bacteria strains degraded mechanically pretreated herbaceous cellulosic wastes and fermented glucose and xylose to ethanol, acetic acid and gaseous products like hydrogen and $\mathrm{CO}_{2}$. Specifically maximum yield of ethanol was reached at $96 \mathrm{~h}$ of fermentation and varied between $2.9-3.2 \mathrm{~g} / 10 \mathrm{~g}$ of substrate. Content of acetic acid didn't exceed $0.35 \mathrm{~g} / \mathrm{l}$. Other volatile fatty acids were detected in trace quantities.
\end{abstract}

Keywords: Thermophilic; Cellulolytic; Saccharolytic; Syntrophic; Consortium; Lignocellulosic waste

\section{Results and Discussion}

65 new strains of anaerobic thermophilic cellulolytic and saccharolytic Clostridia were isolated from different wetlands and hot springs in Georgia. Hipercellulolytic and high effective strains of C. thermocellum and C. thermosaccharolyticum have been screened and studied for tolerance to high substrate and fermentation end products concentration. At the next stage most, effective strains were used for the development of syntrophic mixed-culture for direct conversion of plant biomass with improved ethanol productivity [1]. Plant biomass referred to a lignocellulose, is predominantly composed of three major polymers: cellulose (an insoluble linear unbranched homopolysaccharide consisting of glucose subunits linked via b-1,4 glycosidic bonds, hemicellulose (polysaccharide mainly composed of xylans, mannans, glucans) and lignin (an intricate polyphenolic structure). It is built up as cellulose fibers that are partially arranged in a crystalline structure, integrated with hemicellulose and embedded in a matrix of lignin. Both cellulose and hemicellulose are the sources of fermentable sugars. Compared to starch and sugar crops effective release of fermentable sugars from recalcitrant lignocellulosics is a complex process and therefore requires suitable pretreatment and hydrolysis steps [2].

For our studies wheat straw and corn stalks were selected as lignocellulosic wastes. Before the studies for search of the wastes pretreatment methods, it is important to establish chemical composition of the substrates. Composition of chief chemical compounds in treated and untreated stubbles were determined. Obtained results are given in Table 1. Physical method of treatment of cellulosic substrates, which represents a combination of chilling and milling methods, has been chosen. Mechanical milling of frozen cellulosic wastes enhances subsequent breaking of cellulose that 
lead to further increase of cellulose specific reactionary surface accessible for enzymes. Efficiency of freeze explosion method was estimated according to yield of glucose obtained as a result of enzymatic hydrolysis of raw and pre-treated lignocellulosic substrates like corn stalks and wheat straw. Trichoderma reesi enzyme preparation containing enzyme level of $40 \mathrm{U} / \mathrm{g}$ dry fiber was used for these purposes. Obtained results are given in Table 2. In short term cereal crop like maize and low-cost agricultural residues such as corn stalks are regarded most available for fuel ethanol production in Georgia (Tables 3 \& 4).

Table 1: Ethanol from lignocellulosic wastes. Chemical composition of wheat straw and corn stalks.

\begin{tabular}{|c|c|c|}
\hline \multirow{2}{*}{ \% (dry mass) } & Wheat straw & Corn stalks \\
\hline Cellulose & 41.8 & 34.8 \\
\cline { 2 - 3 } *Glucose & 41.8 & 34.8 \\
\hline Hemicellulose & 22.7 & 26.3 \\
*Xylose & 20.4 & 1.9 \\
*Arabinose & 1.4 & 0.8 \\
*Galactose & 0.5 & 0.5 \\
*Mannose & 0.2 & 5.8 \\
\hline Lignin & 16.0 & 7.3 \\
\hline Crude protein & 3.2 & 18.9 \\
\hline Soluble solids & 11.4 & 8.7 \\
\hline Ash & 4.9 & 2.9 \\
\hline
\end{tabular}

Table 2: Glucose yield under enzymatic hydrolysis of pretreated corn stalks and wheat straw.

\begin{tabular}{|c|c|c|c|c|c|c|}
\hline \multirow{2}{*}{$\begin{array}{c}\text { Cellulosic } \\
\text { substrate }\end{array}$} & \multicolumn{2}{|c|}{ Non-pretreated substrate } & \multicolumn{4}{c|}{ Pretreated substrate } \\
\hline \multirow{3}{*}{ Corn stalks } & \multicolumn{2}{|c|}{ Freezing temperature T $\left(^{\circ} \mathrm{C}\right.$ ) } \\
\cline { 2 - 7 } & $\begin{array}{c}\text { Glucose yield } \\
\text { (mg/g dry fiber) }\end{array}$ & $\begin{array}{c}\text { \%of theoretical } \\
\text { conversion }\end{array}$ & $\begin{array}{c}\text { Glucose yield } \\
\text { (mg/g dry fiber) }\end{array}$ & $\begin{array}{c}\text { \%of theoretical } \\
\text { conversion }\end{array}$ & $\begin{array}{c}\text { Glucose yield } \\
\text { (mg/g dry fiber) }\end{array}$ & $\begin{array}{c}\text { \%of theoretical } \\
\text { conversion }\end{array}$ \\
\cline { 2 - 7 } & 187 & 46.7 & 360 & 78.3 & 376 & 77.2 \\
\hline Wheat straw & 185 & 46.2 & 369 & 80.2 & 386 & 82.5 \\
\hline
\end{tabular}

Table 3: Glucose fermentation to ethanol by the strains of $C$. Thermocellum isolated in Georgia.

\begin{tabular}{|c|c|c|c|c|}
\hline \multirow{2}{*}{ Substrate $\mathbf{( 1 0 g / 1 )}$} & \multirow{2}{*}{ Strain } & \multicolumn{3}{|c|}{ Fermentation end products } \\
\cline { 3 - 5 } & & Ethanol (g/g) & Acetic acid (g/g) & Hydrogen $(\mathbf{l} / \mathbf{g})$ \\
\hline Glucose & GSX-2 & 3.28 & 0.21 & 1.1 \\
\hline Glucose & GSX-4 & 3.54 & 0.34 & 1.2 \\
\hline Glucose & GSX-5 & 3.12 & 0.29 & 1.0 \\
\hline Glucose & GSX-6 & 2.97 & 0.28 & 0.9 \\
\hline
\end{tabular}

Table 4: Fermentation of pretreated corn stalks and wheat straw to ethanol by consortia comprised of cellulolytic and saccharolytic clostridia strains : GSX-2 and GSX-8 and GSX-4 and GSX-9.

\begin{tabular}{|c|c|c|c|c|}
\hline Substrate & $\begin{array}{c}\text { Substrate } \\
\text { concentration }(\mathrm{g} / \mathrm{l})\end{array}$ & Ethanol yield (g/g) & Acetic acid (g/g) & $\begin{array}{l}\text { Hydrogen (1/g } \\
\text { substrate) }\end{array}$ \\
\hline \multirow{3}{*}{ Corn stalks } & 10 & 3.16 & 0.35 & 1.2 \\
\hline & 20 & 6.11 & 0.61 & 2.0 \\
\hline & 30 & 9.23 & 0.96 & 2.8 \\
\hline \multirow{3}{*}{ Wheat straw } & 10 & 2.90 & 0.28 & 1.1 \\
\hline & 20 & 5.90 & 0.60 & 1.9 \\
\hline & 30 & 8.76 & 0.79 & 3.2 \\
\hline
\end{tabular}

Cite this article: Kutateladze L, Urushadze T, Dudauri T, Metreveli B, Zakariashvili N, Xhoxhashvili I, Jobava M. Fermentation of Pretreated 


\begin{tabular}{|c|c|c|c|c|}
\hline Substrate & $\begin{array}{l}\text { Substrate concentration } \\
(\mathrm{g} / \mathrm{l})\end{array}$ & Ethanol yield (g/g) & Acetic acid (g/g) & $\begin{array}{l}\text { Hydrogen (l/g } \\
\text { substrate) }\end{array}$ \\
\hline \multirow{3}{*}{ Corn stalks } & 10 & \multirow{3}{*}{$\begin{array}{l}3.21 \\
6.32 \\
9.04\end{array}$} & 0.32 & 1.2 \\
\hline & 20 & & 0.58 & 1.9 \\
\hline & 30 & & 0.89 & 2.7 \\
\hline \multirow{3}{*}{ Wheat straw } & 10 & 3.18 & 0.30 & 1.0 \\
\hline & 20 & 6.08 & 0.56 & 1.8 \\
\hline & 30 & 8.96 & 0.81 & 2.8 \\
\hline
\end{tabular}

\section{Acknowledgement}

The project $04 / 10$ was funded through the Science and Technology Center in Ukraine (STCU) and Shota Rustaveli National Science Foundation (SRNSF).

\section{References}

1. Ozkan M, Desai SG, Zhang Y, Stevenson DM, Beane J, et al. (2011) Characterization of 13 newly isolated strains of anaerobic, cellulolitic,thermophilic bacteria. J of Industrial Microbiol \& Biotechnol 27(5): 275-280.

2. Sparling R, Islam R, Cicek N, Carere C, Chow H, et al. (2006) Formate synthesis by Clostridium thermocellum during anaerobic fermentation. Canadian Journal of Microbiology 52(7): 681-688.
ISSN: 2574-1241

DOI: 10.26717/BJSTR.2018.10.001945

Kutateladze L. Biomed J Sci \& Tech Res

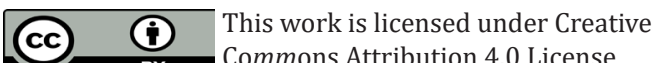

Submission Link: https://biomedres.us/submit-manuscript.php

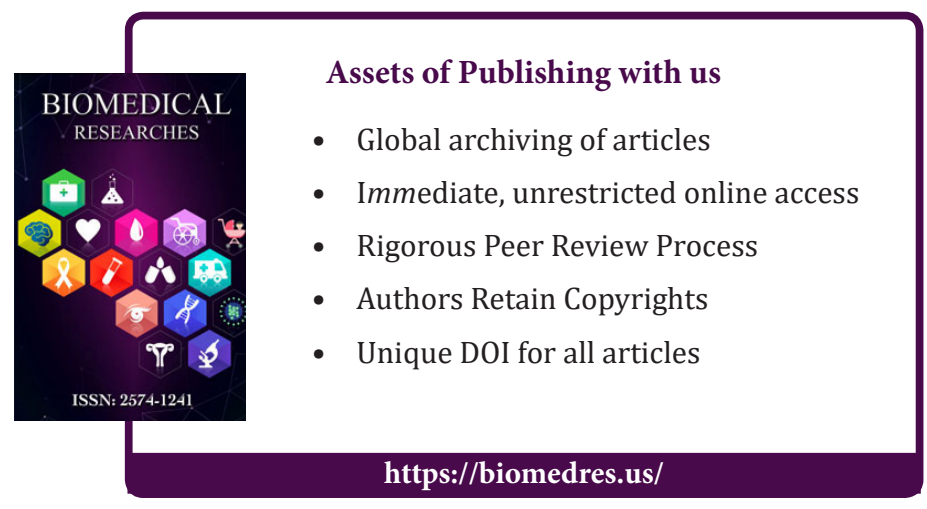

